\title{
Altitudinal Variation in Species Composition and Soil Properties of Banj Oak and Chir Pine Dominated Forests
}

\author{
Munesh Kumar*, Harpal Singh, Jahangeer A. Bhat and G.S. Rajwar \\ Department of Forestry and Natural Resources, HNB Garhwal University Srinagar Garhwal, Uttarakhand 249161, India
}

\begin{abstract}
The study was carried out in two different forest types viz., Banj oak and Chir pine forests to assess the variation in forest species composition and soil properties along altitudinal gradients in the Garhwal Himalayas. The results of the study showed that between the forests soil moisture was higher in Banj oak forest because of closed canopy and dense forest compared to Chir pine forest. The sand particles were reported higher in Banj oak forest which might be due to the addition of organic matter favouring coarse structure of soil, helping in holding maximum water in soils. However in the Chir pine forest low amount of soil organic matter and presence of clayey soil, develops soil compactness which reduces the penetration of water resulting in high soil bulk density. The higher accumulation of litter and presence of moisture in Banj oak forest favours higher nutrient level of nitrogen, phosphorus and potassium compared to Chir pine forest. The soil organic carbon also reduced with increasing altitude at both gradients. While bulk density has reverse trend with soil organic carbon in both the forests at different peaks of same region. In Banj oak forest, the highest density and total basal cover was reported 1,100 tree ha ${ }^{-1}$ and $58.86 \mathrm{~m}^{2} \mathrm{ha}^{-1}$ respectively. However, the highest values of density and total basal cover of Chir pine forest was 560 tree ha ${ }^{-1}$ and $56.94 \mathrm{~m}^{2} \mathrm{ha}^{-1}$ respectively. The total density and basal cover of both the forests reduced with increasing altitude. The study concludes that Banj oak forest has better nutrient cycling ability, well developed forest floor and has a greater protective and productive features compared to the Chir pine forest which is without lower vegetation cover and having only pine litter accumulation which does not allow any other species to grow.
\end{abstract}

Key Words: altitude, soil properties, banj oak, chir pine, himalaya

\section{Introduction}

The altitude and aspect plays a key role in determining the temperature regime of any site. Within one altitude the co-factors like topography, slope, aspect, inclination of slope and soil type also affect the forest species composition (Shank and Noorie 1950, Sharma et al. 2010). Differences in insolation period at various altitudes may occur according to slope aspect of site (Sharma et al.
2010). In Himalayas, the north-facing slopes are relatively cooler because they receive less sunlight compared to other aspects.

The natural distribution of the Himalayan forests from the outer hills to the inner higher zones of the Himalayas is determined primarily by altitude. Although geology, soils and other biotic and abiotic factors are also important to a great extent (Champion and Seth 1968). The physico-chemical characteristics of forest soils differ in space

Received: July 31, 2012. Revised: November 13, 2012. Accepted: November 13, 2012. 
and time because of variations in biotic and abiotic components viz., topography, climate, weathering processes, vegetation cover and microbial activities etc. vegetation plays an important role in soil formation (Champan and Reiss 1992). Thus the resultant production and community structure of vegetation too differ (Ruess and Innis 1977). The natural forest-stands of any place are the result of the interaction of various factors of the soil and the environment. The quantum of biomass produced over a period of time depends largely on the nature, aggregation of species and the nutrient supply potential of the soil. On the other hand, the forests also have a marked influence on the soil structure. The properties of soil developed under a particular regime have a profound influence on the growth and development of plants (Kumar et al. 2004). The type of parent material from which a soil is derived can influence its basic status and nutrient level. The ability of the soil to retain water depends upon the amount of silt and clay particles available in the soil. The effect of the textural properties of the soil is frequently reflected in the composition and the rate of growth of forest vegetation.

Quercus leucotrichophora A. Camus, (Banj oak) is a moderate to large sized evergreen tree which grows on a variety of geological formations and soils, such as shale, gneiss, schist, quartzite and limestone rocks and mostly sandy or clayey loamy soils. It is quite frequent on clayey soils produced from decomposition of shales and micaceous sandy soil resulting from decomposition of mica-schist. It grows best on cool northern aspects with deep moist shale soil; however, its growth gets stunted on shallow and dry soils on the warmer southern aspects, mostly because of insufficient soil moisture (Luna 2005). Pinus roxburghii Sarg., (Chir pine) is a large evergreen tree and a principal species of the Himalayan sub-tropical forest (Champion and Seth 1968).

The present study was focused on, the variation in forest species composition, community structure and soil properties along the different altitudes of two different peaks in Banj oak and Chir pine forest types of Garhwal Himalayas. Therefore, the hypothesis was made that; Is there any variation in forest species composition, community structure and soil properties along the altitudinal gradient of two different forest types at two different peaks in the same region, Therefore to verify the hypothesis two dominant forest types i.e., Banj oak and Chir pine of Garhwal Himalayas were selected along an altitudinal gradient for the study.

\section{Materials and Methods}

\section{Study site}

The present study was carried out in two naturally established dominant forest types i.e., Banj oak (Quercus leucotrichophora) and Chir pine (Pinus roxburghii) forests selected in their respective growing temperate and sub-tropical regions of same area. Each forest type was divided into three altitudes at two different peaks with the difference of 100 meter gap between the altitudes for both the forest types except in Chir pine forest where 200 meter gap has been maintained at upper altitude due to steep terrain. The altitudes of Banj oak forests were selected at 1,700, 1,800 and 1,900 meters whereas the altitudes of Chir pine forests were 700, 800 and 1,000 meters. The Banj oak forest stand was selected near Pauri Garhwal of temperate region, located between $30^{\circ} 07^{\prime} 9.9^{\prime \prime}$ to $30^{\circ} 7^{\prime} 12.3^{\prime \prime} \mathrm{N}$ latitude and $78^{\circ} 47^{\prime}$ $46.5^{\prime \prime}$ to $78^{\circ} 47^{\prime} 42.5^{\prime \prime} \mathrm{E}$ longitude and Chir pine forest stand was selected near Srinagar Garhwal of sub-tropical region, located between $30^{\circ} 12^{\prime} 51.2^{\prime \prime}$ to $30^{\circ} 12^{\prime} 51.0^{\prime \prime} \mathrm{N}$ latitude and $78^{\circ} 48^{\prime} 25.2^{\prime \prime}$ to $78^{\circ} 49^{\prime} 2.2^{\prime \prime} \mathrm{E}$ longitude. The climate of the study area is monsoonic and three marked seasons i.e., summer, winter and rainy, which is conspicuously for the whole year. The snowfall can be observed only in the Banj oak forest particularly in winter season and the mean annual temperature ranges between $1.3^{\circ} \mathrm{C}$ to $30^{\circ} \mathrm{C}$, with mean annual rainfall $500 \mathrm{~mm}$. The relative humidity varies between $54 \%$ and $63 \%$. In the sub-tropical Chir pine forest the mean annual minimum and maximum temperature ranges between $16.45^{\circ} \mathrm{C}$ to $26.80^{\circ} \mathrm{C}$, with mean annual rainfall $252 \mathrm{~mm}$.

\section{Soil analysis}

The soil properties of both forest types was analyzed by collecting 54 samples from different altitudes of Banj oak forest and Chir pine forest at different depths i.e., 0-20, 20-40 and 40-60 cm from each altitude. The analysis was carried out for physical properties (moisture, bulk density (BD), water holding capacity (WHC), texture) and chemical properties $(\mathrm{pH}$, soil organic carbon (SOC), nitrogen $(\mathrm{N})$, phosphorous $(\mathrm{P})$ and potassium $(\mathrm{K})$. The moisture, 
Table 1. Physical properties of soils of Banj oak and Chir pine forests

\begin{tabular}{crrrrrrr}
\hline \multirow{2}{*}{$\begin{array}{c}\text { Forest type/ } \\
\text { altitude }\end{array}$} & Depth $(\mathrm{cm})$ & Moisture $(\%)$ & BD $\left(\mathrm{g} \mathrm{cm}^{-3}\right)$ & WHC $(\%)$ & \multicolumn{2}{c}{ Particle size distribution $(\%)$} \\
\hline Banj oak forest & & & & & Sand & Silt & Clay \\
$1,700 \mathrm{~m}$ & $0-20$ & $18.79 \pm 1.12$ & $0.89 \pm 0.08$ & $59.50 \pm 22.06$ & $74.60 \pm 18.33$ & $21.73 \pm 13.76$ & $3.67 \pm 4.57$ \\
& $20-40$ & $15.85 \pm 3.26$ & $0.92 \pm 0.07$ & $57.39 \pm 18.50$ & $73.70 \pm 7.99$ & $24.49 \pm 5.98$ & $1.80 \pm 2.01$ \\
& $40-60$ & $15.30 \pm 1.87$ & $1.03 \pm 0.14$ & $53.94 \pm 18.56$ & $80.17 \pm 6.77$ & $18.22 \pm 6.55$ & $1.61 \pm 0.89$ \\
$1,800 \mathrm{~m}$ & $0-20$ & $12.02 \pm 1.93$ & $1.07 \pm 0.14$ & $43.11 \pm 1.19$ & $73.12 \pm 13.34$ & $23.99 \pm 11.12$ & $2.89 \pm 2.79$ \\
& $20-40$ & $10.53 \pm 3.42$ & $1.30 \pm 0.48$ & $37.25 \pm 5.63$ & $55.38 \pm 17.10$ & $37.97 \pm 12.20$ & $6.65 \pm 4.98$ \\
& $40-60$ & $9.39 \pm 3.27$ & $1.36 \pm 0.46$ & $34.37 \pm 5.73$ & $67.99 \pm 7.87$ & $28.44 \pm 6.48$ & $3.57 \pm 1.72$ \\
$1,900 \mathrm{~m}$ & $0-20$ & $12.12 \pm 6.66$ & $1.05 \pm 0.08$ & $49.48 \pm 18.49$ & $70.00 \pm 4.48$ & $26.02 \pm 1.63$ & $3.97 \pm 2.85$ \\
& $20-40$ & $12.38 \pm 3.29$ & $1.28 \pm 0.40$ & $40.69 \pm 12.72$ & $67.41 \pm 2.11$ & $27.22 \pm 2.13$ & $5.37 \pm 2.77$ \\
& $40-60$ & $10.72 \pm 3.8$ & $1.44 \pm 0.40$ & $38.30 \pm 11.43$ & $58.73 \pm 8.11$ & $31.60 \pm 8.63$ & $9.67 \pm 3.27$ \\
Chir pine forest & & & & & & \\
$700 \mathrm{~m}$ & $0-20$ & $1.70 \pm 1.31$ & $1.24 \pm 0.13$ & $47.88 \pm 18.13$ & $32.75 \pm 5.02$ & $20.60 \pm 13.04$ & $46.65 \pm 17.79$ \\
& $20-40$ & $4.63 \pm 3.89$ & $1.34 \pm 0.07$ & $35.63 \pm 0.94$ & $19.67 \pm 7.13$ & $29.42 \pm 21.42$ & $50.92 \pm 29.79$ \\
$800 \mathrm{~m}$ & $40-60$ & $4.62 \pm 3.89$ & $1.41 \pm 0.06$ & $35.83 \pm 0.95$ & $22.92 \pm 3.67$ & $29.52 \pm 13.20$ & $47.56 \pm 10.48$ \\
& $0-20$ & $1.87 \pm 0.98$ & $1.29 \pm 0.16$ & $40.09 \pm 4.48$ & $38.84 \pm 2.21$ & $27.23 \pm 7.9$ & $33.93 \pm 10.08$ \\
& $20-40$ & $6.29 \pm 1.34$ & $1.33 \pm 0.18$ & $23.22 \pm 9.91$ & $35.70 \pm 10.61$ & $14.68 \pm 9.35$ & $49.62 \pm 11.82$ \\
$1,000 \mathrm{~m}$ & $40-60$ & $2.55 \pm 0.87$ & $1.34 \pm 0.28$ & $31.74 \pm 4.44$ & $36.19 \pm 5.84$ & $14.20 \pm 9.28$ & $49.61 \pm 11.83$ \\
& $0-20$ & $2.76 \pm 0.30$ & $1.12 \pm 0.09$ & $47.25 \pm 14.12$ & $40.30 \pm 9.23$ & $13.73 \pm 7.36$ & $45.97 \pm 16.52$ \\
& $20-40$ & $4.77 \pm 2.56$ & $1.33 \pm 0.03$ & $31.33 \pm 8.33$ & $40.54 \pm 3.11$ & $12.12 \pm 6.98$ & $47.35 \pm 3.93$ \\
& $40-60$ & $4.78 \pm 2.56$ & $1.45 \pm 0.09$ & $31.42 \pm 7.56$ & $40.87 \pm 10.61$ & $7.63 \pm 7.33$ & $51.50 \pm 12.39$ \\
\hline
\end{tabular}

water holding capacity, bulk density (BD) and texture was determined as the methods described by Misra (1968). Soil $\mathrm{pH}$ was measured with the dynamic digital $\mathrm{pH}$ meter (1:2.5 soil water suspensions). The total nitrogen was measured by Kjeldal procedure and exchangeable phosphorus and available potassium was determined by (Jackson 1958). Soil organic carbon was determined by Walkley and Black's rapid titration method (Walkley and Black 1934).

\section{Phytosociological analysis}

The phytosociological study was carried out by using a quadrat size of $10 \times 10 \mathrm{~m}$ for trees at each altitude, a total of 10 quadrats were laid randomly. Thus 60 quadrats were used at six different altitudes. The size and number of quadrats were based on species area curve (Misra 1968) and the running mean methods (Kershaw 1973). In each quadrate the tree circumference at breast height (at 1.37 $\mathrm{m}$ from the ground) $>30 \mathrm{~cm}$ were considered as trees. The vegetation data was analyzed as the methods described by Curtis and McIntosh (1950) and Curtis (1959).

\section{Results}

\section{Soil properties}

\section{Banj oak forest}

The physical and chemical properties of soil are given in Table 1 and Table 2. At $1700 \mathrm{~m}$ altitude, the moisture ranged from $15.30 \pm 1.87 \%(40-60 \mathrm{~cm})$ to $18.79 \pm 1.12 \%$ $(0-20 \mathrm{~cm})$. The bulk density increased with increase in depth. The WHC was highest at the depth of $0-20 \mathrm{~cm}$. In soil texture, sand particles were the highest at 40-60 cm depth followed by $0-20 \mathrm{~cm}$ and $20-40 \mathrm{~cm}$. Silt was highest in 20-40 cm and lowest at 40-60 cm depth. Clay particles reduced with increasing depths (Table 1). The $\mathrm{pH}$ was acidic in nature. The SOC decreased with increasing depth. Nitrogen, phosphorous and potassium reduced with increasing depths (Table 2).

At $1,800 \mathrm{~m}$ altitude, soil moisture and WHC decreased with the depths (Table 1), however, bulk density showed reverse trend with moisture which increased with increasing depths. The lower amount of sand particles was in $20-40 \mathrm{~cm}$ and higher in 0-20 cm depth (Table 1). The maximum and 
Table 2. Chemical properties of soils of Banj oak and Chir pine forests

\begin{tabular}{|c|c|c|c|c|c|c|}
\hline $\begin{array}{l}\text { Forest type/ } \\
\text { altitude }\end{array}$ & $\begin{array}{l}\text { Depth } \\
(\mathrm{cm})\end{array}$ & $\begin{array}{c}\mathrm{pH} \\
(1.2: 5)\end{array}$ & $\begin{array}{l}\mathrm{SOC} \\
(\%)\end{array}$ & $\begin{array}{c}\text { Nitrogen } \\
(\%)\end{array}$ & $\begin{array}{c}\text { Phosphorus } \\
\text { (kg ha1) }\end{array}$ & $\begin{array}{c}\text { Potassium } \\
\text { (kg ha1) }\end{array}$ \\
\hline \multicolumn{7}{|l|}{ Banj oak } \\
\hline \multirow[t]{3}{*}{$1,700 \mathrm{~m}$} & $0-20$ & $5.5 \pm 0.64$ & $1.30 \pm 0.07$ & $0.064 \pm 0.005$ & $13.23 \pm 1.04$ & $131.5 \pm 12.59$ \\
\hline & $20-40$ & $5.9 \pm 0.32$ & $1.05 \pm 0.16$ & $0.051 \pm 0.007$ & $11.45 \pm 0.90$ & $104.9 \pm 3.94$ \\
\hline & $40-60$ & $5.3 \pm 0.65$ & $0.36 \pm 0.08$ & $0.018 \pm 0.004$ & $9.57 \pm 0.86$ & $88.10 \pm 2.81$ \\
\hline \multirow[t]{3}{*}{$1,800 \mathrm{~m}$} & $0-20$ & $5.7 \pm 0.36$ & $1.40 \pm 0.27$ & $0.072 \pm 0.014$ & $15.89 \pm 1.33$ & $133.28 \pm 16.49$ \\
\hline & $20-40$ & $5.8 \pm 0.1$ & $0.90 \pm 0.03$ & $0.046 \pm 0.002$ & $12.63 \pm 1.97$ & $111.26 \pm 9.05$ \\
\hline & $40-60$ & $5.9 \pm 0.05$ & $0.35 \pm 0.11$ & $0.018 \pm 0.005$ & $10.56 \pm 0.75$ & $82.14 \pm 9.39$ \\
\hline \multirow[t]{3}{*}{$1,900 \mathrm{~m}$} & $0-20$ & $5.4 \pm 0.20$ & $1.30 \pm 0.06$ & $0.065 \pm 0.003$ & $16.08 \pm 0.45$ & $133.65 \pm 0.99$ \\
\hline & $20-40$ & $5.4 \pm 0.26$ & $0.89 \pm 0.07$ & $0.045 \pm 0.003$ & $12.93 \pm 0.17$ & $73.82 \pm 50.73$ \\
\hline & $40-60$ & $5.5 \pm 0.28$ & $0.21 \pm 0.07$ & $0.010 \pm 0.003$ & $11.35 \pm 0.90$ & $89.60 \pm 5.13$ \\
\hline \multicolumn{7}{|l|}{ Chir pine } \\
\hline \multirow[t]{3}{*}{$700 \mathrm{~m}$} & $0-20$ & $6.77 \pm 0.23$ & $1.02 \pm 0.03$ & $0.051 \pm 0.002$ & $24.67 \pm 2.27$ & $146.35 \pm 10.10$ \\
\hline & $20-40$ & $6.50 \pm 0.20$ & $0.80 \pm 0.08$ & $0.040 \pm 0.004$ & $22.29 \pm 2.27$ & $114.61 \pm 11.97$ \\
\hline & $40-60$ & $6.27 \pm 0.15$ & $0.42 \pm 0.03$ & $0.021 \pm 0.002$ & $19.34 \pm 2.75$ & $88.48 \pm 7.35$ \\
\hline \multirow[t]{3}{*}{$800 \mathrm{~m}$} & $0-20$ & $6.97 \pm 0.15$ & $1.07 \pm 0.15$ & $0.053 \pm 0.013$ & $25.94 \pm 1.12$ & $118.24 \pm 47.86$ \\
\hline & $20-40$ & $6.74 \pm 0.11$ & $0.535 \pm 0.07$ & $0.028 \pm 0.003$ & $23.58 \pm 1.51$ & $115.36 \pm 1.11$ \\
\hline & $40-60$ & $6.53 \pm 0.06$ & $0.28 \pm 0.04$ & $0.014 \pm 0.001$ & $21.90 \pm 2.05$ & $89.98 \pm 5.05$ \\
\hline \multirow[t]{3}{*}{$1,000 \mathrm{~m}$} & $0-20$ & $6.97 \pm 0.15$ & $1.125 \pm 0.075$ & $0.056 \pm 0.004$ & $26.25 \pm 1.09$ & $114.96 \pm 79.63$ \\
\hline & $20-40$ & $6.77 \pm 0.12$ & $0.505 \pm 0.12$ & $0.025 \pm 0.005$ & $24.47 \pm 1.04$ & $113.49 \pm 1.72$ \\
\hline & $40-60$ & $6.57 \pm 0.11$ & $0.256 \pm 0.114$ & $0.013 \pm 0.005$ & $21.80 \pm 0.76$ & $86.99 \pm 9.39$ \\
\hline
\end{tabular}

minimum silt and clay was in 20-40 cm and 0-20 cm depths respectively. The $\mathrm{pH}$ was acidic in nature. The SOC, nitrogen, phosphorous and potassium were decreased with increasing depths (Table 2).

At 1,900 $\mathrm{m}$ altitude, the highest moisture percent was at the depth of 20-40 cm and the lowest at the depth of 40-60 $\mathrm{cm}$. The bulk density increased with increasing depth while as WHC showed reverse trend (Table 1). The $\mathrm{pH}$ was also acidic in nature. The SOC, nitrogen, phosphorous and potassium decreased with increasing depth (Table 2).

\section{Chir pine forest}

In Chir pine forest, at $700 \mathrm{~m}$ altitude, the moisture was lowest at 0-20 cm and highest at 20-40 cm. The bulk density increased with increasing depths. The WHC was highest at the depth of 0-20 cm and the lowest at 20-40 cm (Table 1). The proportion of soil particles was higher for clay followed by silt and sand (Table 1). The $\mathrm{pH}$ was slightly acidic which reduced with increasing depths. SOC, nitrogen, phosphorous and potassium decreased with increasing depths (Table 2).

At $800 \mathrm{~m}$ altitude, moisture reduced from $20-40 \mathrm{~cm}$ to
40-60 $\mathrm{cm}$ depth, although moisture was lowest at upper depth $(0-20 \mathrm{~cm})$, however, bulk density showed reverse trend with moisture (Table 1). The WHC was highest at $0-20 \mathrm{~cm}$ depth and lowest at $20-40 \mathrm{~cm}$. The sand particles were higher at $0-20 \mathrm{~cm}$ and lower at $20-40 \mathrm{~cm}$ while clay was highest at $20-40 \mathrm{~cm}$. The silt was maximum at $0-20 \mathrm{~cm}$ and minimum at 40-60 $\mathrm{cm}$ (Table 1). The $\mathrm{pH}$, SOC, nitrogen, phosphorous and potassium were decreased with increasing depths (Table 2).

At 1,000 $\mathrm{m}$ altitude, moisture and bulk density increased with increasing depth (Table 1). The WHC was higher at $0-20 \mathrm{~cm}$ and lower at $20-40 \mathrm{~cm}$ (Table 1). Sand and clay particles were highest in the depth of 40-60 cm while as silt was highest at $0-20 \mathrm{~cm}$ (Table 1). The $\mathrm{pH}, \mathrm{SOC}$, nitrogen, phosphorous and potassium were highest in the soils of $0-20 \mathrm{~cm}$ depth followed by $20-40 \mathrm{~cm}$ and $40-60 \mathrm{~cm}$ depths.

\section{Phytosociological studies}

\section{Banj oak forest}

At 1,700 $\mathrm{m}$ altitude, the quantitative information (density and basal cover) of Banj oak forest is given in Fig. 1A. At this altitude the most dominant tree was $Q$. leucotrichophora 
A

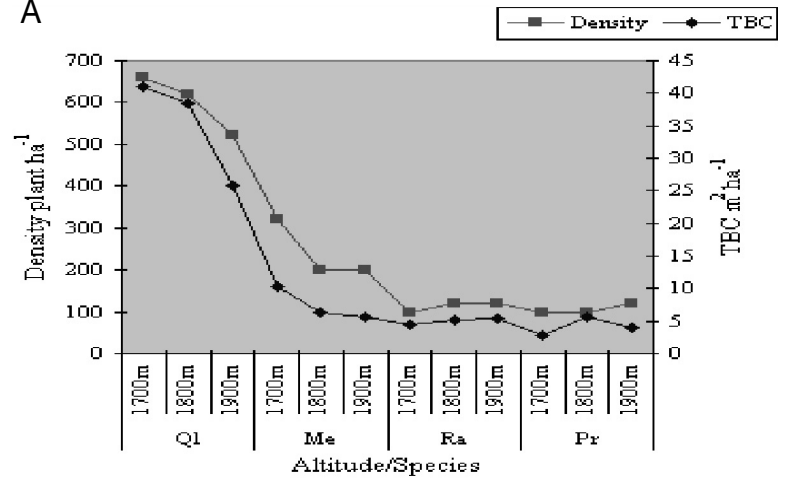

B

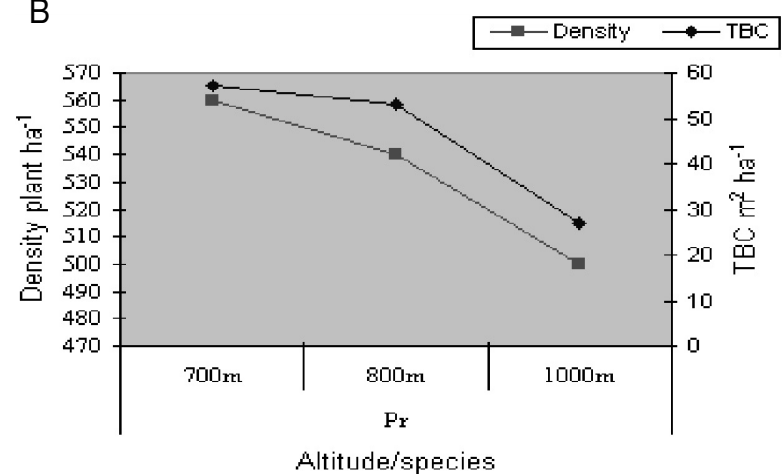

Fig. 1. (A) Density and total basal cover (TBC) of tree species (Q1: Quercus leucotrichophora; Me: Myrica esculenta; Ra: Rhododendron arboreum and Pr: P. roxburghii) in Banj oak forest. (B) Density and total basal cover (TBC) of $\operatorname{Pr}$ (Pinus roxburghii) of Chir pine forest.

Table 3. Correlation coefficient of physical properties of soils among the parameters of Banj oak and Chir pine forests

\begin{tabular}{|c|c|c|c|c|c|c|}
\hline & Altitude (m) & Moisture & $\mathrm{BD}$ & WHC & Sand & Silt \\
\hline \multicolumn{7}{|l|}{ Banj oak } \\
\hline Moisture (\%) & -0.768 & & & & & \\
\hline $\mathrm{BD}\left(\mathrm{g} \mathrm{cm}^{-3}\right)$ & 0.884 & $-0.978^{*}$ & & & & \\
\hline WHC (\%) & -0.724 & $0.998 * *$ & $-0.962 *$ & & & \\
\hline Sand (\%) & -0.871 & $0.984 *$ & $-1.000 * *$ & $0.970^{*}$ & & \\
\hline Silt (\%) & 0.746 & $-0.999 * *$ & $0.971^{*}$ & $-0.999 * *$ & $-0.977 *$ & \\
\hline Clay (\%) & $1.000 * *$ & -0.772 & 0.887 & -0.729 & -0.874 & 0.750 \\
\hline \multicolumn{7}{|l|}{ Chir pine } \\
\hline Moisture (\%) & 0.893 & & & & & \\
\hline $\mathrm{BD}\left(\mathrm{g} \mathrm{cm}^{-3}\right)$ & $-1.000 * *$ & -0.893 & & & & \\
\hline $\mathrm{WHC}(\%)$ & -0.200 & 0.263 & 0.200 & & & \\
\hline Sand $(\%)$ & 0.885 & 0.580 & -0.885 & -0.634 & & \\
\hline Silt (\%) & $-0.980 *$ & -0.786 & $0.980 *$ & 0.390 & $-0.960 *$ & \\
\hline Clay $(\%)$ & 0.167 & 0.593 & -0.167 & 0.933 & -0.312 & 0.033 \\
\hline
\end{tabular}

*Significant at $\mathrm{p}<0.05, *$ Significant at $\mathrm{p}<0.01$.

(IVI-167.26) and least dominant was $P$. roxburghii (IVI-13.34). The other associated trees reported were Myrica esculenta and Rhododendron arboreum. At 1,800 $\mathrm{m}$ altitude, Q. leucotrichophora (IVI-159.85) and P. roxburghii (IVI-38.76) were again most and least dominant tree species respectively however $M$. esculenta and $R$. arboreum were the associated trees. At 1,900 m altitude, the Q. leucotrichophora (IVI-155.80) was again dominant tree but the least dominant species was $R$. arboreum (IVI-40.96) with associated species of $M$. esculenta and $P$. roxburghii.

\section{Chir pine forest}

In the Chir pine forest Pinus roxburghii was the single dominating tree with associated species of herbs and some common shrubs. The quantitative information of Chir pine forest is shown in Fig. 1B. At $700 \mathrm{~m}$ altitude $P$. roxburghii was the dominant tree with highest values of density (560 trees $\left.\mathrm{ha}^{-1}\right)$ and total basal cover $\left(56.94 \mathrm{~m}^{2} \mathrm{ha}^{-1}\right)$. At $800 \mathrm{~m}$ altitude, the density of $P$. roxburghii was 540 tree $^{-1} \mathrm{a}^{-1}$ and total basal cover was $53.26 \mathrm{~m}^{2} \mathrm{ha}^{-1}$. At $1,000 \mathrm{~m}$ altitude, the dominant tree was again $P$. roxburghii with least values of density $\left(500\right.$ trees $\left.\mathrm{ha}^{-1}\right)$ and total basal cover $\left(26.79 \mathrm{~m}^{2}\right.$ $\left.\mathrm{ha}^{-1}\right)$.

\section{Statistical analysis}

The correlation coefficient among the physical properties 
Table 4. Correlation coefficient of chemical properties of soils among the parameters of Banj oak and Chir pine forests

\begin{tabular}{|c|c|c|c|c|c|}
\hline & Altitude (m) & $\mathrm{pH}$ & SOC & $\mathrm{N}$ & $\mathrm{P}$ \\
\hline \multicolumn{6}{|l|}{ Banj oak } \\
\hline $\mathrm{pH}$ & -0.359 & & & & \\
\hline $\mathrm{SOC}(\%)$ & -0.943 & 0.650 & & & \\
\hline $\mathrm{N}(\%)$ & -0.764 & 0.876 & 0.936 & & \\
\hline $\mathrm{P}\left(\mathrm{kg} \mathrm{ha}^{-1}\right)$ & $0.948^{*}$ & -0.044 & -0.788 & -0.519 & \\
\hline $\mathrm{K}\left(\mathrm{kg} \mathrm{ha}^{-1}\right)$ & -0.831 & 0.818 & $0.969^{*}$ & $0.994 * *$ & -0.611 \\
\hline \multicolumn{6}{|l|}{ Chir pine } \\
\hline $\mathrm{pH}$ & 0.807 & & & & \\
\hline $\operatorname{SOC}(\%)$ & -0.754 & $-0.996 * *$ & & & \\
\hline $\mathrm{N}(\%)$ & -0.787 & $-0.999 * *$ & $0.999 * *$ & & \\
\hline $\mathrm{P}\left(\mathrm{kg} \mathrm{ha}^{-1}\right)$ & 0.854 & $0.996^{* *}$ & $-0.986^{* *}$ & $-0.993 * *$ & \\
\hline $\mathrm{K}\left(\mathrm{kg} \mathrm{ha}^{-1}\right)$ & -0.886 & $-0.989 * *$ & $0.973^{*}$ & $0.984 *$ & $-0.998 * *$ \\
\hline
\end{tabular}

*Significant at $\mathrm{p}<0.05, * *$ Significant at $\mathrm{p}<0.01$.

Table 5. ANOVA for chemical properties of soils of Banj oak and Chir pine forests

\begin{tabular}{|c|c|c|c|c|c|c|}
\hline \multirow{2}{*}{ Source of variance } & \multirow{2}{*}{$\mathrm{df}$} & \multicolumn{5}{|c|}{ F-value } \\
\hline & & $\mathrm{pH}$ & SOC & $\mathrm{N}$ & $\mathrm{P}$ & K \\
\hline \multicolumn{7}{|l|}{ Banj oak } \\
\hline Depth & 2 & 0.56 & $171.816^{*}$ & $153.649 *$ & $65.427 *$ & $10.816^{*}$ \\
\hline Altitude & 2 & $2.48 *$ & $1.919^{*}$ & $1.816^{*}$ & $14.258^{*}$ & 0.554 \\
\hline \multicolumn{7}{|l|}{ Chir pine } \\
\hline Depth & 2 & $224.6^{*}$ & $37.564 *$ & $39.054 *$ & 1.047 & $11.582 *$ \\
\hline Altitude & 2 & $90.65 *$ & $1.215^{*}$ & $1.258 *$ & 208.071 & $1.074 *$ \\
\hline
\end{tabular}

* Significant at 0.05 level of significance.

Table 6. ANOVA for physical properties of soils of Banj oak and Chir pine forests

\begin{tabular}{|c|c|c|c|c|c|c|c|}
\hline \multirow{2}{*}{ Source of variance } & \multirow{2}{*}{$\mathrm{df}$} & \multicolumn{6}{|c|}{ F-value } \\
\hline & & Moisture & $\mathrm{BD}$ & WHC & Sand & Silt & Clay \\
\hline \multicolumn{8}{|l|}{ Banj oak } \\
\hline Depth & 2 & $7.134 *$ & $10.752 *$ & $17.258^{*}$ & $0.809^{*}$ & $1.308^{*}$ & 0.273 \\
\hline Altitude & 2 & $46.192 *$ & $17.458^{*}$ & $87.993^{*}$ & $2.474^{*}$ & $2.964 *$ & $1.907 *$ \\
\hline \multicolumn{8}{|l|}{ Chir pine } \\
\hline Depth & 2 & $5.965 *$ & $5.133^{*}$ & $26.305^{*}$ & $1.7463^{*}$ & 0.212 & $2.453 *$ \\
\hline Altitude & 2 & 0.202 & 0.139 & $6.931 *$ & $14.867 *$ & $4.307 *$ & $0.725 *$ \\
\hline
\end{tabular}

*Significant at 0.05 level of significance.

of soil for Banj oak and Chir pine forest is given in Table 3 respectively while correlation coefficient among the chemical properties of soil for Banj oak and Chir pine forest is given in Table 4. The analysis of variance (ANOVA) for chemical properties of soil for Banj oak and Chir pine is given in Table 5 while ANOVA for physical properties of 
A

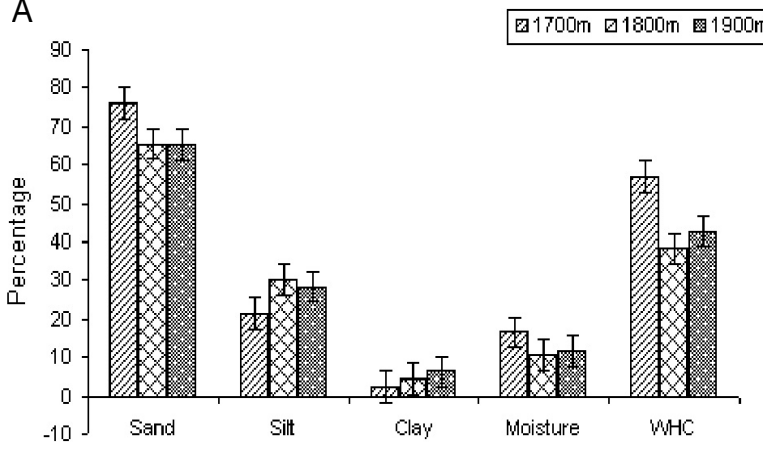

B

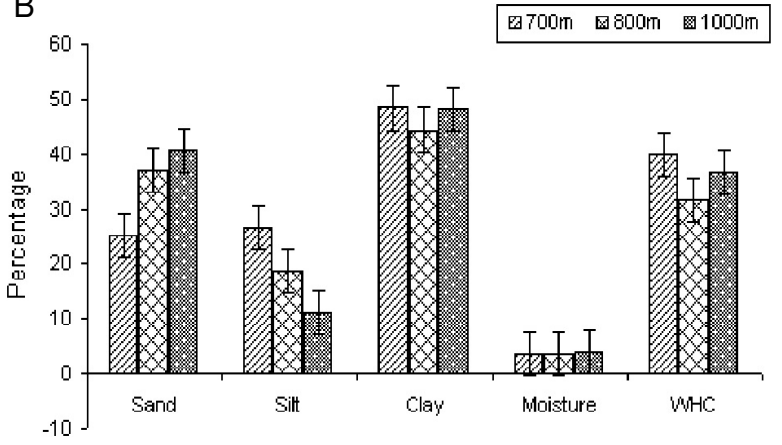

Fig. 2. (A) Physical properties of soil of Banj oak forest. (B) Physical properties of soil of Chir pine forest.

soil for Banj oak and Chir pine forests is shown in Table 6.

\section{Discussion}

In Banj oak and Chir pine forests, the highest moisture was in Banj oak forest compared to Chir pine forest, which may be due to dense canopy and multi-layered of Banj oak forest at higher elevations compared to Chir pine forest which has sparse forest canopy cover, which enhances more light penetration in the forest floor and results in higher evaporation rate and low moisture contents in the soils. Generally Banj oak forests are characteristically moister (Saxena 1979) closed canopied and fire free (Champion and Seth 1968). The relative better conditions of oak forests may be attributed due to closed canopies (Saxena and Singh 1980), compared to Chir pine forests having open canopy (Bargali et al. 1998). A forest having multi-layered canopy with substantial canopy index and depth, and well developed forest floor, has a greater protective value compared to a forest with fewer layers and low canopy index (Lull 1964). The water retention and its movement in soil vary with the texture of soil (Kumar et al. 2002).

The average water holding capacity of Banj oak forest (Fig. 2A) was higher compared to Chir pine forest (Fig. 2B) which was $46.01 \pm 9.75 \%$ and $36.05 \pm 4.08 \%$ for Banj oak and Chir pine forests respectively. These values are within the range, reported for tropical (15.8 to 63.2\%), sub-tropical (31.9 to 42.9\%) and temperate forests (28.1 to $81.2 \%$ ) forests in Garhwal Himalaya (Kumar et al. 2004). In Banj oak forest (Fig. 2A) sand percent was higher while as clay percent was higher in Chir pine forest (Fig. 2B). Sandy soils allow water to enter and pass away rapidly, it warms up quickly and cools very soon compared to other textures (Sharma et al. 2010) and less favorable for tree growth. Although higher amount of clay, reduces penetration of moisture in the soil due to its soil compactness.

In Banj oak forest average soil $\mathrm{pH}$ ranged from $5.5 \pm 0.25(1,900)$ to $5.8 \pm 0.17(1,800 \mathrm{~m})$ and in Chir pine the $\mathrm{pH}$ was slightly higher (ranged from 6.51 \pm 0.19 to $6.77 \pm 0.13$ ) than Banj oak forest. The acidic nature of soil in oak forest could be due to higher number of species and dense composition result in higher input of litter. In Banj oak forest as $\mathrm{pH}$ increases, it also increases the suitability of nitrogen to the plants. The slight acidic nature in $\mathrm{pH}$ level in Chir pine forest is favourable to higher amount of phosphors in the soil for plants.

The SOC and nitrogen in both Banj oak and Chir pine forest decreased with increasing altitude. The SOC and nitrogen of Chir pine forest was lower compared to Banj oak forest. The lower values of SOC and nitrogen in Chir pine could be due to lower density and basal cover of trees which results in low input of litter and provides lower amount of SOM and soil nutrients to forest soil. The phosphorus in both the forests increased with the altitudes. The potassium decreased with increasing altitudes in Chir pine forest (Fig. 3A) but in Banj oak forest it was slightly increased in $1800 \mathrm{~m}$ and again dropped in 1,900 m (Fig. 3B).

The average value of nitrogen, phosphorus and potassium was higher in Banj oak forest compared to Chir pine forest. The values of nitrogen reported (0.25 to $0.31 \%)$ by Bhandari et al. (2000) and 0.10 to $0.20 \%$ by Kumar et al. (2004) for temperate forest was lower than the present study.

The comparison of SOC and BD was compared with the 

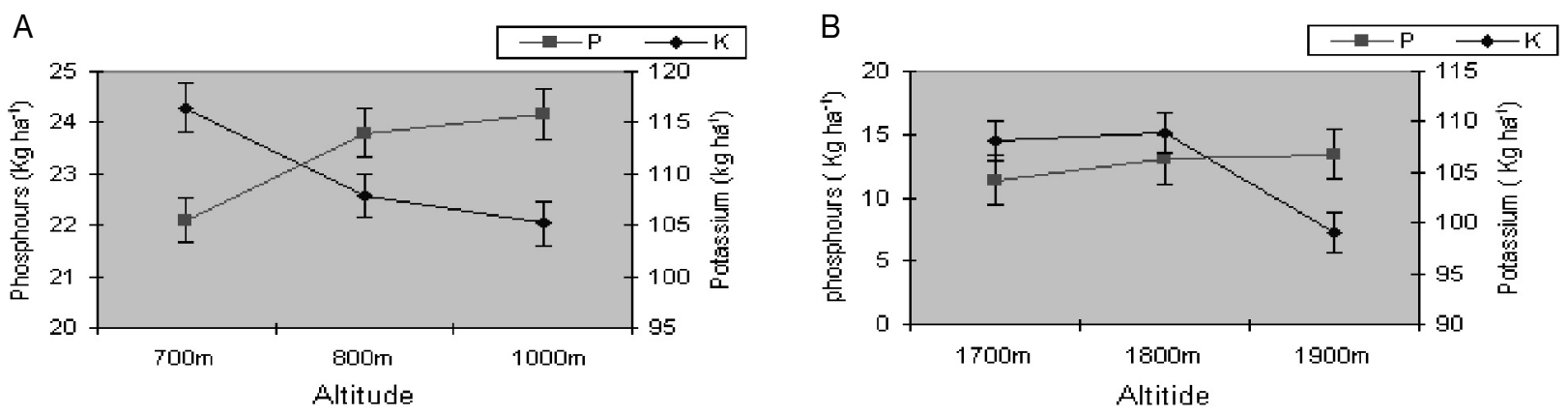

Fig. 3. (A) Soil chemical properties of Chir pine forest. (B) Phosphorus (P) and potassium (K) of soil at different altitudes of Banj oak forest.

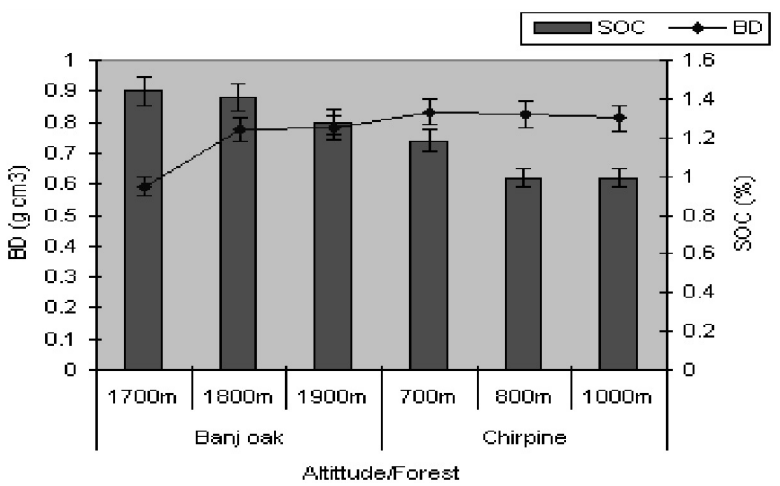

Fig. 4. Bulk density (BD) and soil organic carbon (SOC) in Banj oak and Chir pine forest soils.

altitude (Fig. 4), the study showed that SOC decreased with increasing altitudes because of low input of SOM, however BD showed reverse trend with SOC. Altitude is often employed to study the effects of climatic variables on SOM dynamics (Lemenih and Itanna 2004). Generally, temperature decreased and precipitation increased with increasing altitude. The changes in climate along altitudinal gradients influence the composition and productivity of vegetation and consequently, affect the quantity and turnover of SOM (Quideau et al. 2001). Altitude also influences SOM by controlling soil water balance, soil erosion and geologic deposition processes (Tan et al. 2004). Garten et al. (1999) emphasized the advantages of altitude gradients in forest soil for testing the effects of environmental variables on SOM dynamics. The relationship between SOM and altitude has also been investigated and positive correlations were reported (Sims and Nielsen 1986).

In Banj oak forest, the density of the sites ranged from
960 tree $^{-1}{ }^{-1}$ (site-III) to 1100 tree ha $^{-1}$ (site-I). The total basal cover ranged from $40.88 \mathrm{~m}^{2} \mathrm{ha}^{-1}$ (site-III) to $58.86 \mathrm{~m}^{2}$ $\mathrm{ha}^{-1}$ (site-I). However, in Chir pine forest the density ranged from 500 tree ha $^{-1}$ (site-III) to 560 tree ha $^{-1}$ (site-I) and total basal cover ranged from $26.79 \mathrm{~m}^{2} \mathrm{ha}^{-1}$ (site-III) to $56.94 \mathrm{~m}^{2} \mathrm{ha}^{-1}$ (site-I). These values of density and total basal cover of both the forest reduced with increasing altitudes.

Altitude had a significant effect on species richness and species composition, which declines even with a 100 meter increase in altitude. (Markus et al. 2007). It is suggested that different altitudes and slopes also influence the species richness and dispersion behavior of trees species (Ellu and Obua 2005; Sharma et al. 2009). Kharkwal et al. (2005) have also suggested that altitude and climatic conditions such as temperature and rainfall are the determinants of species richness. The life-forms diversity usually decreases with increasing altitudes and one or two life-form remains at extreme altitudes (Pavon et al. 2000; Sharma et al. 2009). Austin et al. (1996), have analyzed association between of species richness, climate, slope and soil nutrient status. Gairola et al. (2008) also carried out a study of vegetation diversity along an altitudinal gradient in three sites of subalpine forest. The results revealed that the size and density of trees decline sharply from low to high altitude strata.

\section{References}

Austin MP, Pausas JG, Nicholls AO. 1996. Patterns of species richness in realtion to environment in southeastern New South Wales, Australia. Australian Journal of Ecology 21: 154-164.

Bargali KS, Usman R, Joshi M. 1998. Effect of forest covers on certain site and soil characteristics in Kumaun Himalaya. Ind J For 21: 224-277. 
Bhandari S, Mehta JP, Tiwari SC. 2000. Dominance and diversity relation of woody vegetation structure along an altitudinal gradient in a montane forest of Garhwal Himalaya. J Trop For Sc 12: 49-61.

Champan JL, Reiss MJ. 1992. Ecology principles and application. Cambridge University Press, Cambridge, United Kingdom.

Champion HG, Seth SK. 1968. A Revised Survey of the Forest Types of India. Government of India Publication, New Delhi.

Curtis JT. 1959. The Vegetation of Wisconsin. An Ordination of Plant Communities, University Wisconsin Press, Madison Wisconsin.

Curtis JT, McIntosh RP. 1950. The Interrelation of certain analytic and synthetic phytosociological characters. Ecology 31: 434-455.

Ellu G, Obua J. 2005. Tree condition and natural regeneration in disturbed sites of Bwindi Impenetrable forest national park, southwestern Uganda. Tropical Ecology 46: 99-111.

Gairola S, Rawal RS, Todaria NP. 2008. Forest vegetation patterns along an altitudinal gradient in sub-alpine zone of west Himalaya. India African Journal of Plant Science 2: 42-48.

Garten CT, Post WM, Hanson PJ, Cooper LW. 1999. Forest soil carbon inventories and dynamics along an elevation gradient in the southern Appalachian Mountains. Biogeochemistry 45: 115-145.

Jackson ML. 1958. Soil chemical Analysis Prentice Hall, Inc., Engle Wood Cliffs, New Jersey, and USA.

Kershaw KK. 1973. Quantitative and dynamic plant ecology. 2nd ed, FLBS

Kharkwal G, Mehrotra P, Rawat YS, Pangtey YPS. 2005. Phytodiversity and growth form in relation to altitudinal gradient in the Central Himalayan (Kumaun) region of India. Current Science 89: 873-878.

Kumar M, Sharma CM, Rajwar GS. 2004. Physico-chemical properties of forest soil along altitudinal gradient in Garhwal Himalaya. J Hill Res 17: 60-64.

Kumar S, Sharma JC, Sharma IP. 2002. Water retention characteristics and erodibility indices of some soils under different land uses in North-West Himalayas. Ind J Soi Conser 30: 29-35.

Lemenih M, Itanna F. 2004. Soil carbon stocks and turnovers in various vegetation type and arable lands along an elevation gradient in southern Ethiopia. Geoderma 123: 177-188.

Lull HW. 1964. Ecological and silvicultural aspects. In: Hand- book of applied hydrology (Chow VT, ed) McGraw-Hill, New York, pp 6-30.

Luna RK. 2005. Plantation Trees. International Book Distributors, Dehradun.

Markus E, Ladina AM, Salvatore R, Markus N, Rene V. 2007. Effect of climate and vegetation on soil organic carbon, humus fractions, allophones, imogolite, kaolinite and oxyhydroxides in volcanic soils of etna (Sicily). Soi Sci 172: 673-691.

Misra R. 1968. Ecology work book. Oxford and IBH publishing company, New Delhi.

Pavon NP, Hernandez-Trejo H, Rico-Gray V. 2000. Distribution of plant life forms along an altitudinal gradient in the semi arid valley of Zopotitlan, Mexico. J Veg Sci 11: 39-42.

Quideau SA, Chadwick QA, Benesi A, Graham RC, Anderson MA. 2001. A direct link between forest vegetation type and soil organic matter composition. Geoderma 104: 41-60.

Ruess JO, Innis GS. 1977. A Grassland nitrogen flow simulation mode. Ecology 58: 348-429.

Saxena AK. 1979. Ecology of vegetation complex of north- western catchment of river gola. Ph.D. Thesis, Kumaun University, Nanital, India.

Saxena AK, Singh JS. 1980. Analysis of forest grassland vegetation in a part of Kumaun Himalaya. Ind J Rang Man 1: 13-32.

Shank RK, Noories EN. 1950. Microclimate variation in a small valley in Eastern Tannesse. Ecology 11: 531-539.

Sharma CM, Gairola S, Ghildiyal SK, Suyal S. 2010. Physical properties of soils in relation to forest composition in moist temperate valley slopes of the central western himalaya. J For Sci 26: 117-129.

Sharma CM, Suyal S, Gairola S, Ghildiyal SK. 2009. Species richness and diversity along an altitudinal gradient in moist temperate forest of Garhwal Himalaya. J Ameri Sci 5: 119-128.

Sims ZR, Nielsen GA. 1986. Organic carbon in Montana soils as related to clay content and climate. Soi Sci Soc Ameri J 50: 1269-1271.

Tan ZX, Lal R, Smeck NE, Calhoun FG. 2004. Relationships between surface soil organic carbon pool and site variables. Geoderma 21: 185-187.

Walkley AE, Black JA. 1934. An examination of the Degtiga vett. Method for determining soil organic matter and proposed modification of the chromic acid titration method. Soi Sci 37: 29-38. 